\title{
Puncak Prestasi Thariqah Mutakallimin Perspektif Pakhruddin ar-Razi
}

\author{
Nasiri \\ STAI Taruna Surabaya \\ Email: nasiri.abadi@yahoo.co.id
}

\begin{abstract}
Fakhruddin ar-Razi is a great scholar who has mastered various branches of knowledge, especially Islamic sciences. In almost every branch of knowledge he studied, he wrote one or more works, some of which were the main references, such as the book al-Mahshul fi 'Im al-Ushul and Tafsir al-Kabir Mafatih al-Ghaib. Even though he was a follower and defender of the Syafi'i school in the field of fiqh and Asy'ari in the field of kalam, his broad and deep mastery of knowledge and critical thinking about various sciences actually showed his capabilities as a mujtahid.His main work in the field of ushul fiqh, namely al-Mahshul, is the best work that collects four baboon books in the field of ushul fiqh thariqah mutakallimin from his predecessors. He succeeded in presenting ushul fiqh more comprehensively than had been done by his predecessors, including Imam asy-Shafi'i himself. Its analytical-critical descriptions provide depth of understanding of the various matters discussed in the book. Although his work is seen as the result of a merger of the four previous ushul fiqh books, his analyzes and some of his opinions show the independence and originality of the author's thoughts.
\end{abstract}

Key Word: Mutakallimin, al-Razi.

\section{Pendahuluan}

Dunia intelektual Islam klasik memiliki dua nama besar ar-Razi. Yang pertama adalah Abu Bakar Muhammad bin Zakariya ar-Razi atau dikenal sebagai Rhazes di Dunia Barat, merupakan salah seorang pakar sains dan ahli filsafat. Ia lahir di Rayy, Iran, pada tahun 865 M/251 H dan meninggal di sana pula pada tahun $925 \mathrm{M} / 313 \mathrm{H}$. Beliau telah menyumbang dalam bidang pengobatan, kimia dan filsafat. ${ }^{1}$ Sedangkan yang kedua adalah Abu 'Abdillah Muhammad ibn 'Umar ibn al-Husain ibn al-Hasan ibn 'Ali, yang dikenal dengan nama gelar Fakhruddin arRazi atau secara singkat al-Fakhr ar-Razi. Razi yang kedua ini adalah seorang

\footnotetext{
${ }^{1}$ http://ms.wikipedia.org/wiki/Abu_Bakar_Muhammad bin_Zakaria_al-Razi
} 
ensiklopedis yang mendalami, menguasai dan menulis karya-karya dalam bidang tafsir, kalam, fiqh, ushul fiqh, filsafat dan logika. Di antara karya besarnya dalama bidang ushul fiqh adalah al-Mahshul fi 'Ilm al-Ushul.

Tulisan ini ingin mengangkat kebrilianan tokoh ini sehingga dia menguasai berbagai bidang ilmu keislaman dan menghasilkan karya hampir dalam semua bidang yang dipelajarinya, dan bagaimana posisi keilmuannya di dalam belantara intelektual Islam. Lebih khusus, tulisan ini ingin mengungkap dan mengulas karya terpentingya dalam bidang ushul fiqh, yakni al-Mahshul fi ' Ilm alUshul tersebut. Karya yang ditulis pada ketujuh Hijriyah ini juga merupakan karya penting dalam disiplin ilmu ushul fiqh, karena ia telah memuat subjek-subjek ushul fiqh secara cukup komprehensif. Bahkan saat diluncurkannya, karya tersebut bisa dinilai sebagai karya terbaik dalam bidang ini, khususnya di kalangan aliran mutakallimin.

\section{Biografi Fakhruddin ar-Razi}

Fakhruddin ar-Razi lahir pada tanggal 25 Ramadlan di Rayy, sebuah kota kecil di wilayah Persia. Mengenai tahun kelahirannya, para sejarawan berbeda pendapat: apakah $544 \mathrm{H}$ ataukah $543 \mathrm{H}$. As-Subki di dalam Thabaqatnya cenderung kepada tahun 543, sementara adz-Dzahabi dalam as-Siyar memilih pendapat kedua $(544 \mathrm{H})$. Muhammad 'Abd al-Qadir 'Atha, mu'alliq kitab al-Mahshul yang diterbitkan Dar al-Kutub al-'Ilmiyyah tahun 1420/1999 menilai pendapat ini lebih kuat. ${ }^{2}$ Begitu pula Thaha Jabir Fayyadl al-'Ulwani, muhaqqiq kitab al-Mahshul yang diterbitkan Lajnah al-Buhuts wa at-ta'lif wa at-tarjamah wa an-nasyr Riyadl tahun 1981. Ia berargumen dengan perkataan al-Fakhr ar-Razi dalam tafsirnya terhadap surat Yusuf ketika ia menjelaskan tawakkal, "Pengalaman ini telah saya alami sejak usia dini hingga sekarang ini di mana usiaku mencapai 57 tahun.” Sementara, al-Fakhr ar-Razi sendiri mengatakan bahwa ia menyelesaikan penulisan

${ }^{2}$ Muhammad 'Abdul Qadir 'Atha, "al-Imam Abu 'Abdillah Fakhruddin ar-Razi fi Suthur" dalam al-Imam Abi 'Abdillah Muhammad ibn 'Umar ibn al-Husain Fakhruddin ar-Razi, al-Mahshul fi 'Ilm alUshul (Beirut: Dar al-Kutub al-'Ilmiyyah, 1999), I: a 
tafsir surat tersebut pada tahun 601. Sehingga dapat disimpulkan bahwa dia lahir pada tahun $544 \mathrm{H}^{3}$

Fakhruddin ar-Razi sangat beruntung. Ia dilahirkan dan dibesarkan dalam keluarga intelektual. Ayahnya, Imam Dliya'uddin 'Umar termasuk salah seorang ulama besar Syafi'iyyah, orator dan tokoh intelektual di kota Rayy, ahli fiqh, ushul fiqh dan sastra. Ia mempunyai karya-karya dalam bidang fiqh dan kalam. Yang terpenting di antaranya adalah Ghayah al-Maram fi 'Ilm al-Kalam, sebuah kitab yang dinilai oleh as-Subki sebagai salah satu kitab yang paling luas dan paling cermat dalam khazanah Sunni.

Al-Fakhr ar-Razi kecil berada dalam bimbingan ayahnya tersebut. Sehingga bagi dia, ayahnya adalah orang tua sekaligus gurunya dalam arti yang sebenar-benarnya. Dia mencukupi kebutuhan intelektual al-Fakhr ar-Razi sehingga tidak perlu belajar dengan orang lain, sampai saat ia dipanggil oleh Tuhan pada tahun $559 \mathrm{H}$. Dari ayahnya itu pula al-Fakhr ar-Razi pertama kali belajar ushul fiqh.

Selain dukungan keluarganya, al-Fakhr ar-Razi juga dikaruniai daya ingat yang mengagumkan, pikiran yang kritis dan kecerdasan yang luar biasa serta kemauan untuk belajar yang tinggi, yang jarang dimiliki orang lain pada masanya. Karena itu, dia mampu dalam waktu singkat menguasai banyak kitab para pendahulunya, seperti asy-Syamil fi 'Ilm al-Kalam karya Imam al-Haramain, alMustashfa karya al-Ghazali dan al-Mu'tamad karya Abu al-Husain al-Bashri alMu'tazili. Bahkan kedua kitab induk ushul fiqh ini berhasil dihafal di luar kepala. ${ }^{4}$

Fakhruddin ar-Razi hidup pada seluruh paruh kedua abad ke-6 H. dan enam tahun dari paruh pertamanya serta enam tahun pula dari abad ke-7 H. Tahuntahun ini merupakan tah un paling kritis dunia Islam. Ekspansi Kristen-Barat yag telah dimulai pada tahun $494 \mathrm{H}$. masih terus berlangsung hingga hampir 200 tahun lamanya. Dinasti 'Abbasiyah saat itu berada dalam periode kedua di mana khalifah hanya sekedar simbol, sementara kekuasaan terpecah-pecah di tangan para sultan di wilayah masing-masing. Kehancuran umat Islam secara politik ini berpengaruh besar terhadap kondisi sosial ekonomi mereka saat itu.

${ }^{3}$ Thaha Jabir Fayyadl al-"Alwani, "Muqaddimah al-Muhaqqiq" dalam Fakhruddin ar-Razi, alMahshul fi 'Ilm Ushul al-Fiqh (Riyadl: Lajnah al-Buhus wa at-Ta'lif wa at-Tarjamah wa an-Nasyr, 1981), I : 3 .

${ }^{4}$ Ibid. 
Meskipun begitu, kehidupan intelektual dan kebudayaan tetap hidup dan bersemangat. Perhatian para intelektual dan dukungan para penguasa teradap pengembangan ilmu pengetahuan tetap besar. Mereka mendirikan sekolah-sekolah dan membiayai penyelenggaraan pendidikan dan penerbitan.

Rayy, kota di mana Fakhruddin ar-Razi lahir dan tumbuh besar, juga sangat berpengaruh terhadap perkembangan dan karakter intelektualnya. Meskipun kecil, kota ini menjadi pusat berkumpulnya berbagai pemikiran dan mazhab, sehingga seolah-olah kota ini begitu luas. Di dalamnya terdapat representasi dari hampir setiap pemikiran dan aliran dari berbagai bidang ilmu. Semuanya hidup dalam kota kecil ini dalam bentuk yang mengagumkan. ${ }^{5}$

\section{Pendidikan Fakhruddin ar-Razi}

Al-Fakhr ar-Razi berpendapat bahwa mempelajari ilmu, semua ilmu, hukumnya wajib syar'i. Karena itu, dia mencintai dan menekuni berbagai ilmu tanpa membeda-bedakan, kecuali dari sisi bahwa sebagian lebih utama daripada yang lain. Menurutnya, ilmu apapun pasti akan bernilai wajib, atau menjadi penyempurnya yang wajib (la yatimmu al-wajib illa bihi), atau diperlukan untuk mewujudkan kemaslahatan, atau perlu dipelajari untuk mengetahui madlarat dan bahayanya selanjutnya, mengajak orang untuk menjauhinya. ${ }^{6}$ Karena itu, Fakhruddin ar-Razi mempelajari berbagai cabang ilmu: tafsir, kalam, fiqh, ushul fiqh, filsafat, tasawuf, kedokteran dan psikologi, sebagaimana tercermin dari buku-buku yang ditulisnya dan para tokoh yang menjadi gurunya.

Setelah belajar dari ayahnya, al-Fakr ar-Razi melanjutkan pendidikannya dengan sejumlah guru yang merupakan ulama-ulama terkemuka pada masa itu. Dia mengunjungi dan tinggal di beberapa kota, yaitu Khawarizmi, Khurasan , Herat (Afganistan), untuk belajar dan mengajar. ${ }^{7}$ Di antara guru-gurunya adalah: ${ }^{8}$

\footnotetext{
${ }^{5}$ Ibid., h. 1-2.

${ }^{6}$ Ibid., h. 3-4.

7 Sya'ban Muhammad Isma'il, Ushul al-Fiqh: Tarikhuhu wa Rijaluhu (Mekkah: Dar as-Salam,

8 “Abdul Qadir 'Atha, “al-Imam...”, h. a-b.
} 1998), h. 238. 
1. Salman ibn Nasir ibn 'Imran ibn Muhammad ibn Isma'il ibn Ishaq ibn Zaid ibn Ziyad ibn Maymun ibn Mahran, Abu al-Qasim al-Anshari, salah seorang murid Imam al-Haraimain.

2. 'Abd al-Malik ibn 'Abdullah ibn Yusuf ibn 'Abdullah ibn Yusuf ibn Muhammad, yang terkenal dengan nama Imam al-Haramain Dliya'uddin Abu al-Ma'ali al-Juwaini.

3. Ibrahim ibn Muhammad ibn Ibrahim ibn Mahran, al-Imam Ruknuddin Abu Ishaq al-Isfirayani, seorang pakar teologi dan hukum Islam dari Khurasan.

4. Abu al-Husain Muhammad ibn Muhammad ibn 'Abdurrahman ibn as-Sa'id al-Bahili.

5. 'Ali ibn Isma'il ibn Ishaq ibn Salim ibn Isma'il ibn Abdullah ibn Musa ibn Bilal ibn Abu Bard ibn Abu Musa, seorang teolog yang terkenal dengan nama asy-Syaikh Abu al-Hasan al-Asy'ari al-Bashri.

6. Muhammad ibn 'Abdul Wahhab ibn Salam Abu Ali al-Jubba'i, seorang tokoh teolog Mu’tazilah.

7. al-Husain ibn Mas'ud ibn Muhammad Abu Muhammad al-Baghawi. Dari tokoh ini, Fakhruddin ar-Razi mendalami filsafat di samping dari guru lainnya, terutama Majduddin al-Jilli.

8. Al-Husain ibn Muammad ibn Ahmad al-Qadli, Abu 'Ali al-Maruzi.

9. 'Abdullah ibn Ahmad ibn 'Abdullah al-Maruzi, Abu Bakr al-Qaffal ashShaghir.

10. Muhammad ibn Ahmad ibn 'Abdullah

11. Ibrahim ibn Ahmad Abu Ishaq al-Maruzi

12. Ahmad ibn 'Umar ibn Sari' al-Qadli Abu al-'Abbas al-Baghdadi.

13. 'Usman ibn SA'id ibn Bashr Abu al-Qasim al-Anmati al-Baghdadi alAhwal.

14. Isma'il ibn Yahya ibn Isma'il ibn 'Amr ibn Ishaq, Abu Ibrahim al-Mazni alMishri

15. Muhammad ibn Idris ibn al-'Abbas ibn 'Usman ibn asy-Syafi' ibn as-Sayb ibn 'Ubaid ibn Abu Yazid ibn Hasyim ibn 'Abdul Muthallib kakek Rasulullah saw. 


\section{Puncak Pencapaian Thariqah Mutakallimin}

Menurut al-Razi bahwa turuq al-fiqh ada dua macam: 'aqliyyah dan sam'iyyah. Bagi al-Fakhr ar-Razi, yang berbeda dengan Mu'tazilah, thuruq 'aqliyyah tidak dapat digunakan untuk mengetahui hukum. Karenanya tidak perlu dibahas. Sedangkan thuruq sam'iyyah ada dua macam: manshushah dan mustanbathah. Thuruq manshushah dapat berupa perkataan atau perbuatan dari sumber yang tidak bisa salah yaitu Allah, Rasul dan ummat jika mereka berijma'. Yang bersumber dari Rasul dan ummat dapat berupa perkataan ataupun perbuatan. Karena perbuatan tidak bisa bermakna (la yadullu) kecuali jika didukung dengan perkataan maka pembahasan dalalah qawliyyah didahulukan daripada dalalah fi'liyyah.

Namun sebelum membahas aspek-aspek dalalah qawliyyah, al-Fakhr arRazi merasa perlu mendiskusikan terlebih dahulu persoalan-persoalan bahasa (lughat). Hal ini mengingat bahwa penggunaan dalil-dalil manshushah hanya mungkin dilakukan dengan media bahasa.

Selanjutnya, kajian terhadap dalalah qawliyyah mesti melihat dua aspek, yaitu aspek intrinsik (dzatuha), yakni perintah dan larangan (al-amr wa an-nahy), dan aspek ekstrensik ('a waridluha) yang juga dapat dilihat dari dua sisi: sisi obyeknya (muta'allaqatuha), yaitu al-'umum wa al-khushush, dan sisi cara penunjukan maknanya (kayfiyah dalalatiha), yaitu al-mujmal wa al-mubayyan. Bagi al-Fakhr ar-Razi, aspek intrinsik perlu mendapat perhatian lebih dahulu daripada aspek ekstrinsik, karena itu pembahasan al-amr wa an-nahy didahulukan daripada pembahasan al- 'umum wa al-khushush.

Meskipun sama-sama merupakan aspek ekstrinsik, pembahasan almujmal wa al-mubayyan dile takkan setelah al-'umum wa al-khushush karena, menurut al-Fakhr ar-Razi, al-mujmal wa al-mubayyan adalah persoalan hubungan antara perintah dan larangan dengan obyeknya, sedangkan al-'umum wa al-khushush adalah persoalan obyek itu sendiri. Selesai membahas aspekaspek yang berkaitan dengan dalalah qawliyyah, barulah al-Fakhr ar-Razi membahas dalil yang berbentuk perbuatan, yaitu af'al ar-Rasul. 
Pada bagian selanjutnya, al-Fakhr Razi langsung membahas persoalan nasikh-mansukh. Penempatan persoalan ini sebelum ijma' dan qiyas mungkin nampak tidak runtut. Namun bagi al-Fakhr ar-Razi, penempatan ini justru logis dan konsisten. Sebuah dalil bisa berfungsi menetapkan hukum baru atau menghapuskan hukum yang sudah ada. Sedangkan ijma' dan qiyas menurutnya tidak dapat menghapus ataupun dihapus. Karena itulah pembahasan ijma' diletakkan setelah pembahasan nasikh-mansukh.

Karena dalil-dalil manshushah, baik berupa perkataan maupun perbuatan, sampai kepada kita melalui pemberitaan, maka pada bagian akhir pembahasan tentang dalil-dalil manshushah, al-Fakhr ar-Razi membahas persoalan pemberitaan atau periwayatan (al-akhbar). Dan sampai di sini, selesailah pembahasan tentang dalil-dalil manshushah.

Berikutnya, al-Fakhr ar-Razi membahas dalil mustanbath yaitu qiyas. Inilah satu-satunya dalil mustanbath yang dibahas di sini. Hal ini menunjukkan bahwa hanya qiyas-lah yang benar-benar diakui al-Fakhr ar-Razi sebagai dalil mustanbath. Karena itu, pembahasan qiyas mengakhiri pembahasan-pembahasan seputar thuruq al-fiqh.

Selanjutnya, al-Fakhr ar-Razi membahas bagian kedua dari obyek ushul fiqh, yaitu cara (kaifiyyah) beristidlal dengan thuruq al-figh. Hanya ada satu bahasan dalam bagian ini, yaitu tentang ta'adul dan tarjih.

Berkaitan dengan bagian ketiga, yakni kualifikasi orang yang beristidlal, umat Islam terbagi menjadi dua: orang alim yang harus berijtihad dan orang awam yang cukup meminta dan menerima fatwa. Karena itu al-Fakhr ar-Razi membahas 1) syarat-syarat dan ketentuan-ketentuan berijtihad, dan 2) pemberi fatwa dan peminta fatwa.

Terakhir, al-Fakhr ar-Razi membahas secara singkat-singkat thuruq alfiqh yang diperselisihkan, yaitu prinsip bahwa sesuatu yang bermanfaat pada dasarnya dibolehkan dan sesuatu yang mudlarat pada dasarnya dilarang, prinsip istishab al-hal, mashlahah mursalah (munasibah), istihsan, dan qaul shahabi. Meskipun mengakui tiga prinsip yang disebutkan pertama, tetapi ia tidak menganggapnya sebagai thuruq mustanbathah, melainkan prinsip yang sekedar 
merupakan penerapan dari nash. ${ }^{9}$ Sementara dua prinsip yang disebutkan terakhir dipandangnya tidak dapat dijadikan hujjah, karena istihsan merupakan takhshish al-illah, sesuatu yang tidak dapat diterima dan kehujjahan qawl shahabi mempersyaratkan sikap taqlid buta, sesuatu yang juga tidak dapat dibenarkan.

\section{Sumber-sumber Hukum Menurut al-Fakhr ar-Razi}

Sebagaimana nampak dari sistematika penulisan al-Mahshul, al-Fakhr arRazi tidak menyediakan bab tersendiri untuk membahas secara berurutan sumber-sumber hukum (mashadir al-ahkam). Bahkan dia tidak menggunakan istilah "mashadir al-ahkam" sama sekali ketika membahas af'al ar-Rasul dan ijma'. Istilah yang dia gunakan adalah thuruq al-fiqh dan adillah asy-syar'. Ada tiga sumber hukum yang dia sebut dengan istilah thuruq al-fiqh, yaitu al-Qur'an, Sunnah dan ijma' sebagai ath-thuruq al-manshusah, dan satu yang dia sebut dengan istilah ath-thariq al-mustanbath, yaitu qiyas. Sementara, sumber-sumber yang lain ia sebut dengan istilah adillah asy-syar' dan dikategorikan sebagai dalil-dalil yang diperselisihkan.

Para pakar ushul fiqh memang sering kali membedakan istilah-istilah mashdar (j. mashadir), dalil (j. adillah) dan thariq (j. thuruq). Mashdar seringkali digunakan secara lebih terbatas, yaitu hanya untuk al-Qur'an dan Sunnah. Sementara, dalil dan thariq digunakan secara umum, mencakup semua sumber dan metode hukum, mulai dari al-Qur'an, Sunnah, ijma', qiyas, istihsan dst. Meskipun istilah dalil dan thariq seringkali digunakan secara sama, tapi penggunaan kedua istilah itu oleh al-Fakhr ar-Razi untuk menyebut dua kategori yang berbeda nampaknya sengaja dilakukan untuk menegaskan perbedaan keduanya.

Al-Fakhr ar-Razi sama sekali tidak membahas kedudukan al-Qur'an dan Sunnah sebagai sumber atau dalil hukum Islam. Nampaknya, bagi ar-Razi tidak ada persoalan tentang kehujjahan keduanya. Al-Qur'an jelas merupakan kitab suci Islam sehingga bagi umatnya ia bersifat taken for granted dan disepakati

\footnotetext{
${ }^{9}$ Fakhruddin ar-Razi, al-Mahshul fi 'Ilm al-Ushul, I: h. 36-38.
} 
keasliannya. Begitu pula dengan kedudukan Muhammad sebagai utusan Allah, yang berkonsekuensi melekatnya otoritas keagamaan pada diri beliau. Menerima Islam sebagai agama berarti menerima al-Qur'an sebagai aturan hidupnya dan Muhammad saw. sebagai teladannya.

Yang dipandangnya mengandung persoalan adalah masalah tasyri'iyyah atau normativitas perbuatan (af'al) Rasul dan periwayatan (khabar) Sunnahnya. Fuqaha' berbeda pendapat tentang normativitas perbuatan Rasul: apakah pada dasarnya perbuatannya menunjukkan hukum wajib, sunnah ataukah mubah. Imam Malik menganggapnya mubah, Imam Ibn Suraij, Abu Sa'id al-Ishthahri dan Abu Ali bin Khairan menilainya wajib, sementara Imam asy-Syafi'i diinformasikan berpendapat sunnah. Menurut ar-Razi, yang tepat adalah bahwa normativitas perbuatan Rasul membutuhkan petunjuk. Apakah wajib, sunnah ataukah mubah tergantung petunjuk yang ada. ${ }^{10}$ Selanjutnya, karena perbuatan dan perkataan Rasul tidak langsung kita lihat dan kita dengar, maka persoalan pemberitaan menjadi menentukan. Ar-Razi membahas persoalan khabar mutawatir dan kriterianya, khabar tidak mutawatir tetapi dapat diketahui kebenarannya, dan khabar yang diketahui kepalsuannya.

Ar-Razi juga meyakini kehujjahan ijma'. Hanya saja, ia menolak keqath'iannya. Menurutnya, dalil-dalil yang menjadi dasar kehujjahan ijma' hanya bersifat zhanni, tidak ada yang qath'i. Karena itu, meskipun dalil-dalil tersebut memadai untuk menjadi dasar kehujjahan ijma', tetapi keberadaan ijma' sebagai hujjah pun hanya bersifat zhanni. ${ }^{11}$ Begitu pula, ia menilai klaim bahwa suatu hukum telah disepakati (mujma' 'alaih) hanya bersifat dugaan (zhanni), tidak bersifat pasti (qath 'i). Hal ini karena pengetahuan tentang terjadinya ijma' hanya dapat diperoleh dengan cara yang tidak sampai tingkat meyakinkan. ${ }^{12}$

Keteguhan ar-Razi nampak sangat kuat dalam berpegang pada Qiyas. Ia memaparkan secara panjang lebar argumen-argumen kelompok yang menolak qiyas, dan mengemukakan analisis kritis dan sanggahan terhadap argumen-

\footnotetext{
${ }^{10}$ Al-Fakhr ar-Razi, al-Mahshul, jilid 1 hlm. 414..

${ }^{11}$ Ibid., jilid 2, hlm. 25.

${ }^{12}$ Ibid., hlm. 8.
} 
argumen tersebut, sembari mengemukakan argumen-argumen yang meneguhkan kehujjahan qiyas. ${ }^{13}$

Ar-Razi juga berpendapat bahwa istishab al-hal merupakan hujjah dalam menetapkan hukum. Hal ini sebagaimana dikatakannya, berbeda dengan pendapat mayoritas ushuli baik di kalangan Hanafiyyah maupun Mutakallimin. Menurutnya, kehujjahan istishab al-hal adalah karena pengetahuan tentang kepastian hal tersebut berkonsekuensi memperanggapkan terus berlangsungnya hal tersebut. Sesuatu yang memang sudah diketahui hukumnya tidak perlu dicari lagi dalil untuk menetapkannya kembali, sementara untuk menetapkan hukum lain yang belum diketahui diperlukan dalil baru yang menjadi dasarnya. Pendapat ar-Razi ini sejalan dengan fuqaha' asy-Syafi'iyyah. ${ }^{14}$

Ia juga sejalan dengan asy-Syafi'i dalam penolakannya terhadap istihsan. ${ }^{15}$ Menurutnya, perbedaan pendapat mengenai kehujjahan istihsan bukan karena perbedaan dalam memahami istilah tersebut. Mereka yang menolak istihsan bukan karena kesalahpahaman mereka tentang makna istilah tersebut sebagaimana yang dipahami oleh mereka yang mengakui kehujjahannya, melainkan karena substansi prinsip tersebut. Menurut ar-Razi, istihsan merupakan takhshish al- 'illah, sesuatu yang tidak bisa dibenarkan. ${ }^{16}$

Ia juga menolak kehujjahan qawl shahabi. Penolakannya ini menurutnya didasarkan pada nash, ijma' dan qiyas. Nash memerintahkan untuk mengambil pelajaran (fa'tabiru ya ulil albab), yang berarti melarang untuk taqlid, termasuk taqlid kepada sahabat. Bahkan para sahabat sendiri berijma' tentang bolehnya menyelisihi pendapat seorang sahabat, seperti Abu Bakar dan Umar. ${ }^{17}$

Namun demikian, ia mengakui kehujjahan mashlalah mursalah. Setelah mengemukakan klasifikasi dan criteria maslahah yang dibuat oleh al-Ghazali dan Malik, ar-Razi berpendapat bahwa klasifikasi mashlahah yang dibuat oleh Imam Malik semuanya menjadi tujuan syari'ah. Menurutnya, al-Qur'an dan Sunnah menunjukkan keberadaan mashlahah-mashlahah tersebut, kadang-kadang secara

\footnotetext{
${ }^{13}$ Ibid., hlm. 220-263.

${ }^{14}$ Ibid., hlm. 475-476.

15 Asy-Syafi'i, ar-Risalah, tahqiq Ahmad Muhammad Syakir, (Beirut: Dar al-Kutub al-'Ilmiyyah,

${ }_{16}^{16}$ Al-Fakhr ar-Razi, al-Mahshul, jilid 2 hlm. 584-587.

${ }^{17}$ Ibid., hlm. 506.
} tth.), hlm. 504-507. 
jelas, dan kadang-kadang dalam bentuk ketentuan-ketentuan hukum yang sejalan dengan salah satu mashlahah tersebut. Lebih dari itu, kehujjahan mashlahah mursalah juga didasarkan pada nash (fa'tabiru), ijma' dan akal. Meskipun mashlahah bersifat zhanni, tidak sampai qath'I, tetapi sesuatu yang zhanni sudah cukup untuk dijadikan pegangan, berdasarkan sabda Rasul "aqdli bi azh-zhahir" (saya membuat keputusan hukum berdasarkan bukti-bukti yang nampak jelas). ${ }^{18}$

\section{Penutup}

Fakhruddin ar-Razi tidak diragukan lagi, merupakan ulama besar yang menguasai berbagai cabang ilmu, terutama ilmu-ilmu keislaman. Dalam hampir setiap cabang ilmu yang dipelajari, dia menulis satu atau lebih karya yang sebagian di antaranya menjadi referensi utama, seperti kitab al-Mahshul fi 'Ilm al-Ushul dan Tafsir al-Kabir Mafatih al-Ghaib. Meskipun ia adalah pengikut dan pembela mazhab Syafi'i dalam bidang fiqh dan mazhab Asy'ari dalam bidang kalam, tetapi penguasaan ilmunya yang begitu luas dan dalam serta pemikiran kritisnya mengenai berbagai ilmu sesungguhnya menunjukkan kapabilitasnya sebagai seorang mujtahid.

Karya utamanya dalam bidang ushul fiqh, yakni al-Mahshul tersebut, merupakan karya terbaik yang menghimpun empat kitab babon dalam bidang ushul fiqh thariqah mutakallimin dari para pendahulunya. Dia berhasil menghadirkan ushul fiqh secara komprehensif lebih dari yang telah dilakukan oleh pendahulunya, termasuk Imam asy-Syafi'i sendiri. Uraiannya yang bersifat analitis-kritis memberikan kedalaman pemahaman tentang berbagai hal yang didiskusikan dalam kitab tersebut. Meskipun karyanya tersebut dipandang sebagai hasil penggabungan dari empat kitab ushul fiqh sebelumnya, tetapi analisis-analisis serta beberapa pendapatnya menunjukkan kemandirian dan orisinalitas pemikiran penulisnya.

\footnotetext{
${ }^{18}$ Ibid., hlm. 500-502.
} 


\section{Daftar Pustaka}

Al-'Alwani, Thaha Jabir Fayyadl, "Muqaddimah al-Muhaqqiq" dalam Fakhruddin ar-Razi, al-Mahshul fi 'Ilm Ushul al-Fiqh, Riyadl: Lajnah al-Buhus wa at-ta'lif wa at-tarjamah wa an-nasyr, 1981.

Armando, Nina M., dkk. Ensiklopedi Islam, Jakarta: Ichtiar Baru van Hoeve, 2005 .

'Atha, Muhammad 'Abdul Qadir, "al-Imam Abu 'Abdillah Fakhruddin ar-Razi fi Suthur" dalam al-Imam Abi 'Abdillah Muhammad ibn 'Umar ibn alHusain Fakhruddin ar-Razi, al-Mahshul fi 'Ilm al-Ushul, Beirut: Dar al-Kutub al'Ilmiyyah, 1999.

Hallaq, Wael B., Melacak Akar-akar Kontroversi, terjemahan Abdul Basith Junaedy, Surabaya: Srikandi, 2005.

Isma'il, Sya'ban Muhammad, Ushul al-Fiqh: Tarikhuhu wa Rijaluhu, Mekkah: Dar as-Salam, 1998.

Ar-Razi, Fakhruddin, al-Mahshul fi 'Ilm al-Ushul, Beirut: Dar al-Kutub al-'Ilmiyyah, 1999.

Asy-Syafi'I, Muhammad bin Idris, ar-Risalah, tahqiq Ahmad Muhammad Syakir, Beirut: Dar al-Kutub al-'Ilmiyyah, tth.

http://ms.wikipedia.org/wiki/Fakhruddin_al-Razi

http://ms.wikipedia.org/wiki/Abu Bakar Muhammad bin Zakaria al$\underline{\text { Razi }}$

http://www.islamicweb.com/beliefs/fiqh/alalwani usulalfiqh/ch5.htm 